\title{
Freedom of Religion in the Italian Constitution
}

\author{
Renata Tokrri \\ PhD, Lecturer at the University "Aleksandër Moisiu" Durres-Albania
}

\section{Abstract}

In Italy, Catholicism was the dominant faith for about two thousand years and until recently almost the only one. This has meant that it has taken root in the country as a primary socio-cultural element also for the laity and non-believers. Every legal system in a democratic state must find the normative mechanisms to guarantee and protect the religious phenomenon. With the advent of the Republican Constitution, the religious phenomenon is foreseen and regulated in four articles: Articles 7, 8, 19, 20 of the Constitution, to which we must add the guarantees deriving from articles 2 and 3 of the Constitution. These Articles sanction the principle of equality of all confessions and non-discrimination on a religious basis, the freedom to profess one's beliefs both individually and collectively, in public or private, ect. The analysis aims to understand the capacity of these provisions to guarantee all dimensions of the religious phenomenon. In this regard, the question arose whether these articles protect freedom of conscience, conscientious objection and atheism. It is also important to analyze those are the limits that this freedom encounters.

Keywords: Italian Constitution, Freedom of religion, Freedom to professione's belief, Freedom of conscience, Conscientious objection.

\section{Introduction}

\section{Constitution and religion}

A few years before the birth of the republican constitution, many scholars had expressed reflections on religious freedom.

Togliatti considered that the future Constitution had to sanction the "freedom of conscience, faith, worship, propaganda and religious organization" (Report of the 5th Congress of the Italian Communist Party, 1945; Cfr F. MARGIOTTA BROGLIO, 1978, p. 104.), Jemolo also believed that the Constitution could not "renounce the postulate of religious freedom" (A. C. JEMOLO, 1944, p. 33; Cfr. G. LONG, 1990, pp. 268, 270).

A few years later, the latter strongly criticized the Charter, confessing that he did not like it and declaring that it outlined the foundations of a "neither secular nor confessional" (A. C. JEMOLO, 1996; Cfr. P. VALBUSA, 2008, pp. 96 e ss).

Occhiocupo too saw in the Republican Charter, not only a compromise document, but " $a$ constitution inspired by an intimately Christian conception" (V. FAGIOLO, 1990, p. 166).

Regarding the religious phenomenon in the Fundamental Charter (G. CATALANO, 2007; A. RAVÀ, 1959; P. FEDELE, 1963; P. DE LUCA, 1969; P. DI MARZIO, 2000; D. LOPRIENO, 2009; R. 
BIN, 1996; G. DALLA TORRE, 2006), it is foreseen and regulated in four articles: articles 7, 8, 19,20 of the Constitution, to which we must add the guarantees deriving from articles. 2 and 3 of the Constitution. The Council also held, with the sentence no. 14 of 1973, that freedom of religion must be traced back to the inviolable rights provided for by art. 2 of the Constitution. The Court expresses itself in these terms, "The Constitution, by recognizing the inviolable rights of man (art. 2) and, among them, the freedom of religion (art. 8 and 19), protects religious sentiment and justifies the sanction criminal offenses against it".

An interesting observation is that which considers freedom of religion in the Charter as a flexible form, since neither sectoral boundaries are assigned to it. In the sense that it is not restricted only to the private dimension, but also to the social one (P. CONSORTI, 2010, pp. 59, 60).

Thus article 19 of the Constitution, concerning these dimensions, states that: "Everyone has the right to freely profess their religious faith in any form, individual or associated, to promote it and to practice it in private or in public, as long as they do not these are rites contrary to morality".

In the preparatory work for this article, the Hon. Giuseppe Dossetti - in the session of 18 December 1946 He had advanced with a more detailed idea of freedom of religion. Specifically, he had proposed that "Every man has the right to the free profession of his own ideas and convictions, to the free and full explanation of his inner and outer religious life, to the free manifestation, individual and associated, of his own faith, to the propaganda of it, to free private and public exercise of one's own cult, provided that it is not a religion or cult involving principles or rites contrary to public order and morality". (The Constitution of the Republic in the preparatory work of the Constituent Assembly, 1970, Vol. VI, p. 787).

The following day he proposed a new text specifying that "Every man has the right to the free profession of his own ideas and convictions, to the free and full explanation of his inner and outer religious life, to the free manifestation, individual and associated, of his own faith, to propaganda of it, to the free exercise, private and public, of one's own cult, provided that it is not a religion or cult involving principles or rites contrary to public order and morality" (The Constitution of the Republic in the preparatory work of the Constituent Assembly, 1970, Vol. VI, p. 802).

Art. 19 of the Constitution clearly contains the principle in religious matters and refers to three basic faculties, understood as three subjective rights: of profession, of propaganda and of worship. This constitutional provision is understood in doctrine as a form that specifies the freedom to freely express one's thought, since these freedoms concern thought of a religious nature, even if it is not limited to it alone.

It is noted in the doctrine that freedom of profession does not necessarily imply

belonging to a religious confession, in the sense that one can be religious even without belonging to a specific cult (P. CONSORTI).

And since religion is not expressed only individually, the Constituents have provided for another form: the associated one. Thus, also "the faculty of religious profession in associated form pertains to individuals as such and does not attribute rights to their possible association in the act or acts of profession. (...) Cases of freedom to be qualified as individualistic and nonfunctional"( So P. GROSSI, 2008, p. 127; Cfr. C. ESPOSITO, 1958, p. 8). 
For this faculty it is also believed that it is a form that specifies art. 18 of the Constitution, which provides for the rights to associate freely without any authorization. This article, together with art. 20 of the Constitution, also strengthens and protects religious associations.

The Constitutional Court, with sentence no. 59 of 1959, based on the right to worship in open or closed places, declared unconstitutional the rules that provided for government authorization for the construction of non-Catholic temples or places of worship. Ruini defined this norm as a "vigorous affirmation of freedom and conscience and faith, which (...) will honor our Constitution" (In these terms Ruini in his speech to the Assembly of 12 April 1947; Cfr. G. LONG, pp. 216, 319; ID, 1991, pp. 59, 60).

In the matter of the profession of faith, the right to confidentiality is also guaranteed, understood as a right for the individual not to disclose their religious affiliation and beliefs in the matter (P. CONSORTI, p. 62; Cfr., A. C. JEMOLO, 1979, p. 118).

At the same time, there is no doubt, despite the hesitations of a certain doctrine on the subject, that art. 19 of the Constitution in sanctioning the freedom of propaganda in favor of one's creed, offers full guarantee to the activities related to it, such as above all that which consists in proselytism.

It is also believed that both freedom of worship and freedom of propaganda appear juridically as specific forms and consequences of the freedom to profess faith (P. CONSORTI, pp. 62 e ss).

The freedoms protected in this area mainly refer to a dimension external to the individual (B. MARCHETTI, 2011, p. 3), which is why the freedom of propaganda is guaranteed not only by art. 19 of the Constitution, but also by other articles: such as the freedom to freely express one's thoughts through speech, writing or any other means of dissemination, and the freedom to assemble peacefully even in public places.

It should also be considered that propaganda in religious matters is not always neutral, that is, when the subject is not limited to simply expressing his or her thoughts in religious matters, it takes the forms of proselytism. Since for some religious denominations - such as Jehovah's Witnesses for example - proselytism is an important moment, the doctrine believes that this form is also implicitly guaranteed by the Constitution.

Concerning the religious propaganda, the sentence of March 13, 2003 of the Court of Appeal of Brescia, called to ascertain the legitimacy of the dismissal of a messenger who had left paper pamphlets published by Jehovah's Witnesses on a shelf where other magazines were in the room waiting for the Lecco Nursing Home, managed by an order of Catholic nuns, where he was sent due to his duties.

In the first instance, the Judge, considered that the conduct was indicative of individualistic and absolutist overestimation of one's rights, lacking respect for the contiguous rights of others of equal constitutional importance and that the same had determined a serious situation of potential danger in relation to the prosecution and the correct performance of contractual relations between the employer company, which carries out clinical analysis laboratory activities, and its customers, rejects the application.

In reverse, the Court of Appeal found that "the distinction between religious propaganda and free expression of thought can be shared, in order to exclude the former from the protection pursuant to Article 1 of Law no. 300/70 and art. 21 cost. during working hours, however, 
religious propaganda cannot be considered an intrinsically negative fact", declares the dismissal illegitimate.

It emerges, from a first reading of art. 19 of the Constitution a total lack of its negative correspondence. That is, the freedom not to profess or exercise any religious faith. However, it is believed that art. 19 of the Constitution also accepts, certainly implicitly, religious dissent. It is the task of the legislator to guarantee the freedom not to profess, not to exercise and not to express oneself in accordance with a specific faith.

The Fundamental Charter underlines and strengthens the protection of individual freedoms by attributing to the right to adhere or not to a specific faith an absolute value that cannot and must not be subjected to any conditioning or forcing.

In this context, while on the one hand there is the explicit recognition of the freedom to believe, on the other there is, albeit implicitly, the freedom not to believe.

\section{Article 19 of the Constitution and the right to exercise their religion in public or in private}

Additional guarantee recognized by the constitutional text in art. 19 of the Constitution is the faculty to practice worship in public or in private, with the sole limit of morality. This freedom of enjoyment is guaranteed in any form, including associative $\left({ }^{1}\right)$.

According to part of the doctrine, this freedom does not find constitutional coverage in art. 17 of the Constitution. In this perspective, the protection of the freedom to celebrate a rite is guaranteed in art. 19 of the Constitution and prevails over the protection of freedom of assembly (P. CONSORTI, p. 66).

In fact, a link between art. 19 and 17 of the Constitution is noted because the exercise of a cult may require a form such as a meeting. Cardia believes that it is not possible to hold a religious meeting in a private place that is not intended for the purpose of worship (C. CARDIA, 2005, p. 133).

This thesis cannot be accepted, because, in reference to art. 17, also the Constitutional Court with the sentence n. 45 of 1957 declared art. 25 of the 1931 Consolidated Law on public security, in the part in which it provided for an obligation of notice for religious functions, ceremonies and practices in places open to the public; while, a year later with sentence no. 27, illegality also affected the rules contained in art. 18 of the Consolidated Law on public security laws, approved with Royal Decree 18 June 1031, n. 773, in the part relating to meetings not held in a public place - that is, in private places - always referring to art. 17 of the Constitution.

\footnotetext{
1 This freedom is strengthened at the constitutional level by art. 17 and 18 of the Constitution. The first states that "Citizens have the right to gather peacefully and without arms. For meetings, even in places open to the public, no notice is required. For meetings in public places, notice must be given to the authorities, who may prohibit them only for proven reasons of public safety or security". Instead the second establishes that "Citizens have the right to associate freely, without authorization, for purposes that are not prohibited to individuals by criminal law. Secret associations and those that pursue, even indirectly, political purposes through organizations of a military nature are prohibited".
} 
In particular, the Court found a sort of analogy of art. 19 with art. 17, "when the exercise of worship takes place in an associated form, these rules must be considered with art. 17, "in an evident relationship of coordination, in the sense that meetings of a religious nature do not escape the general discipline of all meetings, as regards the freedom of the meetings themselves and the limits to which it, in the best interest of social coexistence, is submitted"( Thus the Constitutional Court, sentence no. 45 of 1957, in the Official Gazette no. 77 of 23 March 1957). When, therefore, religious behavior is carried out in the form of a meeting, then art. 19 of the Constitution must be read in combination with art. 17 of the Constitution.

In particular, the Court found a sort of analogy of art. 19 with art. 17, "when the exercise of worship takes place in an associated form, these rules must be considered with art. 17, "in an evident relationship of coordination, in the sense that meetings of a religious nature do not escape the general discipline of all meetings, as regards the freedom of the meetings themselves and the limits to which it, in the best interest of social coexistence, is submitted"( Thus the Constitutional Court, sentence no. 45 of 1957, in the Official Gazette no. 77 of 23 March 1957). When, therefore, religious behavior is carried out in the form of a meeting, then art. 19 of the Constitution must be read in combination with art. 17 of the Constitution.

\section{The discipline of limits}

As regards the discipline of limits, it must first be stated that the Italian Constitution does not identify "a single situation of freedom, but provides for and distinguishes a plurality of rights having the same structure, but a different content" and for each of these freedoms it is a specific ad hoc regulation of limits and guarantees is envisaged (C. CARDIA, 2005, p. 650).

The only explicit limit (G. DELLA TORRE, 1995, pp. 57, 58.) provided for religious freedom is the obscure, indefinite, and "uncertain outlines" (P. CONSORTI, p. 68.) of morality, however a part of the doctrine believes that there is also the limit of public order, which consists of situations of public security, safety and tranquility.

A rule that helps to define the concept of morality is art. 529 c.p. which actually offers a very vague definition of an obscene act, considering for the purposes of criminal law "the acts and objects which, according to the common sentiment, offend modesty". In this norm, as observed not only by doctrine but also by jurisprudence, any manifestation of concupiscence, of sensuality, can be considered an obscene act. In other words, the obscene is understood as sexual modesty and sexual morality, where the parameter for evaluating obscenity is the common feeling.

Part of the doctrine believes that in reality, the limit of morality provided for by art. 19 of the Constitution is "largely obsolete" because the possibility that a religious rite is contrary to sexual morality is quite difficult (P. CONSORTI, p. 68.); the other party, rather, has tried to broaden the aforementioned limit, considering it applicable to ritual cases involving the sacrifice of animals. Here it must be emphasized that, in reality, the sacrifice of religious animals is compatible with the general rules of the European Union.

For this reason, it can be considered that the limit of morality is an expression attributed to criminal law. However, the Supreme Court (Court of Cassation, VI Criminal Section, Sentence of 10 July 2008, n. 28720) held that followers of the Rastafarian religion can possess quantities of marijuana in excess of the legal threshold (A. BETTETINI, 2009, p. 3). 
It is also pointed out that this limit "is not particularly penetrating, since the public authorities can only intervene in a repressive and not preventive way" (M. MADONNA, 2012, p. 49). Its intent is not to forbid the belief itself but the ritual manifestations that present these characteristics.

\section{Conclusions}

It is noted that Article 19 of the Constitution, which can be considered as a flexible formula concerning both the private and social dimensions, refers to three basic faculties, understood as three subjective rights: profession, propaganda and exercise of worship.

We can believe that this article together with others, appears sufficient to guarantee freedom of religion in any form, even in the associative one. In fact, it guarantees the freedom to declare and manifest one's faith or opinions on the matter, but also to exercise the cult in which one adheres both in public and in private.

In addition, it should be noted that in the matter of profession of faith, the right to privacy is also guaranteed, understood as a right for the individual not to disclose their religious affiliation and beliefs in the matter. At the same time, there is no doubt that art. 19 of the Constitution, in sanctioning the freedom of propaganda in favor of one's belief, offers full guarantee to the activities related to it, such as above all that which consists in proselytism.

Another important aspect is also the decisions of the Constitutional Court, which has intervened on the matter several times, protecting these dimensions of freedom of religion.

It should be noted that a real lacuna can be seen in the Italian Constitution, that inherent in the citizen's right to any conviction, freedom of conscience, conscientious objection and atheism, as they do not find explicit expression in the Fundamental Charter. These freedoms must be extrapolated, identified, interpreted through the fundamental principles of the Constitution.

Therefore, an ad hoc discipline would undoubtedly appear to be the best solution in a Constitution so incomplete and deficient on the issue of conscience and atheism.

\section{Bibliography}

[1] Bettetini a., Brevi Riflessioni Sulla Recente Giurisprudenza "Apicale" in Ambitò Ecclesiastico, in Stato, Chiese E Pluralismo Confessionale, 2009, in Www.Statoechiese.It.

[2] Cardia C., Principi Di Diritto Ecclesiastico: Tradizione Europea Legislazione Italiana, Giappichelli, Turin, 2005.

[3] Catalano G., Il Diritto Di Libertà Religiosa, Giuffrè, Milan, 1957, (Reprinted, Cacucci, Bari, 2007).

[4] Consorti P., Diritto E Religione, Laterza, Rome-Bari, 2010.

[5] Dalla Torre G., Giurisprudenza Costituzionale E Dottrina Ecclesiasti Cistica, Saggio Di Analisi, Edited by R. Botta, in Diritto Ecclesiastico E Corte Costituzionale, Edizioni Scientifiche Italiane, Naples, 2006.

[6] De Luca P., Il Diritto Di Libertà Religiosa Nel Pensiero Costituzionalistico Ed Ecclesiasticistico Contemporaneo, Cedam, Padua, 1969.

[7] Della Torre G., Il Fattore Religioso Nella Costituzione, Giappicchelli, Turin, 1995.

[8] Di Marzio P., Contributo Allo Studio Del Diritto Di Libertà Religiosa, Jovene, Naples, 2000. 
[9] Esposito C., La Libertà Di Manifestazione Del Pensiero Nell'ordinamento Italiano, Giuffrè, Milan, 1958.

[10] Fedele P., La Libertà Religiosa, Giuffrè, Milan, 1963.

[11] Grossi P., Il Diritto Costituzionale Tra Principi Di Libertà E Istituzioni, 2ed., Cedam, Padua, 2008.

[12] Jemolo a. C., La Costituzione. Difetti, Modifiche, Integrazioni, Relazione Tenuta All'accademia Dei Lincei (1965), Rome, 1996.

[13] Jemolo a. C., Lezioni Di Diritto Ecclesiastico, Ved., Giuffrè, Milan, 1979.

[14] Jemolo a. C., Per La Pace Religiosa in Italia, La Nuova Italia, Florence, 1944.

[15] La Costituzione Della Repubblica Nei Lavori Preparatori Dell'assemblea Costituente, Edition Edited by the Chamber of Deputies - General Secretariat, Rome, 1970, Vol. Vi.

[16] Long G., Alle Origini Del Pluralismo Confessionale, Il Dibattito Sulla Libertà Religiosa Nell'età Della Costituente, Il Mulino, Bologna, 1990.

[17] Long G., Le Confessioni "Diverse Dalla Cattolica", Il Mulino, Bologna, 1991.

[18] Loprieno D., La Libertà Religiosa, Giuffrè, Milan, 2009.

[19] Madonna M., Profili Storici Del Diritto Di Libertà Religiosa Nell'italia Post-Unitaria, Libellula, Lecce, 2012.

[20] Marchetti B., Libertà Religiosa E Cedu, in Ius Publicum Network Review, Www.IusPublicim.Com, Annual Report, 2001, Italy, September 2011.

[21] Margiotta Broglio F., Stato E Confessioni Religiose, 2, in Teorie E Ideologie, La Nuova Italia, Florence, 1978.

[22] Ravà a., Contributo Allo Studio Dei Diritti Individuali E Collettivi Di Libertà Religiosa Nella Costituzione Italiana, Giuffrè, Milan, 1959.

[23] Report of the 5th Congress of the Italian Communist Party, 1945.

[24] Valbusa P., I Pensieri Di Un Malpensante. Arturo Carlo Jemolo E Trentacinque Anni Di Storia Repubblicana, Marsilio, Venice, 2008.

[25] Vv. Aa., Costituzione E Realtà Attuale 1948-1988, Edited by Di L. Lippolis, Giuffrè, Milan, 1990.

[26] Vv. Aa., I Soggetti Del Pluralismo Nella Giurisprudenza Costituzionale, Edited by R. Bin, C. Pinelli, Giappichelli, Turin, 1996. 